\title{
Genetic structure of Antioquia Holstein from two SNPs and association with dairy traits
}

\section{Estructura genética del Holstein Antioqueño a partir de dos SNP y asociación con características lecheras}

\author{
Stephania Madrid G, ${ }^{1 *}$ M.Sc, Albeiro López $H_{,}{ }^{1}$ Ph.D, Julián Echeverri Z, ${ }^{1}$ Ph.D.
}

${ }^{1}$ Universidad Nacional de Colombia, Facultad de Ciencias Agrarias, Departamento de Producción Animal, Grupo de Investigación BIOGEM, Calle 59 A No. 63 - 20, Medellín, Colombia. *Correspondence: smadridg@unal.edu.co.

Received: November 2014; Acepted: March 2015.

\begin{abstract}
Objective. Analyze the structure and genetic differentiation of a population of Antioquia Holstein cows from the polymorphisms A192G of INHA and A-320T of FSHR, and explore the association of the genotypic combinations with milk traits. Materials and methods. 1240 lactations of 356 animals from 9 herds in 6 municipalities of Antioquia were analyzed. Genotyping was performed by PCR-RFLP. Structure and genetic diversity parameters were determined using GenAlex software. The association of genotypes combinations with productive and reproductive traits was explored through a linear mixed model. Results. SNP A192G showed a frequency of 0.534 and 0.466 for A and G alleles respectively and SNP A-320T had a frequency of 0.660 far $A$ allele and 0.339 for $T$ allele, this way the population is in HWE. The $\mathrm{F}_{\mathrm{ST}}, \mathrm{F}_{\mathrm{IS}}$ and $\mathrm{F}_{\mathrm{IT}}$ values were $0.059,0.285$ and 0.328 respectively indicating a moderate genetic differentiation between subpopulations. The A-320T SNP showed significant effect on milk yield. Fat and protein percentage, calving interval and services per conception were not affected by these polymorphisms or their interaction. Conclusions. Phenotypic selection made on this population has not been strong enough to generate noticeable changes in allele frequencies of these polymorphisms or deviations from Hardy-Weinberg equilibrium. The interaction of these polymorphisms has no significant effect on the characteristics of zootechnical interest, so its use in programs of molecular marker assisted selection is not recommended.
\end{abstract}

Key words: Dairy cattle, polymorphism, population genetic, SNP-RFLP (Source: AGROVOC).

\section{RESUMEN}

Objetivo. Analizar la estructura y diferenciación genética de una población de vacas Holstein de Antioquia a partir de los polimorfismos A192G de INHA y A-320T de FSHR, y explorar la asociación de las combinaciones genotípicas con características de importancia económica en lecherías especializadas. Materiales y métodos. Se analizaron 1240 lactancias, de 356 animales de 9 hatos en 6 municipios de Antioquia. La genotipificación se realizó mediante PCR-RFLP. Se determinaron parámetros de estructura y diversidad genética utilizando el software GenAlex. La asociación de las combinaciones de genotipos con características productivas y reproductivas se exploró mediante un modelo linear mixto. Resultados. El SNP A192G presentó una frecuencia de 0.534 y 0.466 para el alelo A y G respectivamente y el SNP A-320T tuvo una frecuencia de 0.660 para el alelo A y 0.339 para el alelo T, encontrándose la población en HWE. Los valores $F_{S T} F_{I S}$ y $F_{I T}$ fueron $0.059,0.285$ y 0.328 respectivamente indicando una moderada diferenciación genética éntre subpoblaciones. El SNP A-320T presentó efecto 
significativo sobre la producción de leche. El porcentaje de grasa, proteína, intervalo entre partos y servicios por concepción no se vieron afectados por los polimorfismos o su interacción. Conclusiones. La selección fenotípica realizada sobre esta población no ha sido lo suficientemente fuerte para generar cambios notorios en las frecuencias alélicas de estos polimorfismos ni desviaciones del equilibrio de Hardy-Weinberg. La interacción de estos polimorfismos no presenta un efecto significativo sobre las características de interés zootécnico por lo cual no se recomienda su uso en programas de selección asistida por marcadores moleculares.

Palabras clave: Ganado lechero, genética poblacional, polimorfismo, SNP-RFLP (Fuente: AGROVOC).

\section{INTRODUCTION}

The genetic variability of a population is influenced by the number of founding individuals, genetic drift, strategy and selection intensity (1), while the population structure can be affected by the interchange of genetic material among populations, the reduction of population size, and the decrease in the number of male reproducers, among other factors (2).

The breeding programs implement in developing countries based on importation of genetic material, but the majority of this comes from populations with low genetic variability and high levels of endogamy due to using the few genetically superior individuals that are used for mating, putting at risk the sustainability of the improvement programs (2).

In the dairy herds in Antioquia, artificial insemination is implemented as the principal tool for genetic improvement. Techniques such as multiple ovulation and embryo transfer and producing embryos in vitro are implemented with lesser proportion in order to obtain individuals with high genetic merit that improve the productive levels of those systems.

Among the existing methodologies to select superior individuals we find marker assisted selection (MAS), which are sites in the genome where differences exist in the nucleotide sequence between individuals of the same species, generating single nucleotides polymorphism (SNP) that can be identified by the PCR-RFLP (3). These polymorphisms can also be used to know the structure and diversity of a population (4). The SNP A192G is found in the exon 1 of the inhibin alpha gene (INHA), and since it is a synonymous mutation it does not change the protein amino acid sequence, but rather generates an additional restriction site for the MspI endonuclease $(5,6)$. The SNPA-320T is found upstream from the follicle stimulating hormone receptor gene (FSHR) and although it is not found in any codifying region, it can modulate gene expression and also change the restriction pattern obtained in the Taq1 enzyme $(7,8)$.

\section{INTRODUCCIÓN}

La variabilidad genética de una población se ve influenciada por el número de individuos fundadores, la deriva genética, la estrategia y la intensidad de selección (1), mientras que la estructura poblacional puede ser afectada por el intercambio de material genético entre poblaciones, la reducción en el tamaño de la población, la disminución en el número de machos reproductores entre otros factores (2).

Los programas de mejoramiento genético implementados en los países en desarrollo se basan en la importación de material genético, pero la mayoría de este proviene de poblaciones con baja variabilidad genética y altos niveles de endogamia debido al uso de pocos individuos genéticamente superiores que por lo general están emparentados, poniendo en riesgo la sostenibilidad de los programas de mejoramiento (2).

En los sistemas de producción lecheros de Antioquia, se implementa la inseminación artificial como principal herramienta para el mejoramiento genético. Técnicas como la ovulación múltiple y transferencia de embriones y la producción de embriones in vitro son implementadas en menor proporción con el fin de obtener individuos de alto mérito genético que permitan mejorar los niveles productivos en estos sistemas.

Entre las metodologías existentes para seleccionar individuos superiores se encuentra la selección asistida por marcadores moleculares (SAM), son sitios en el genoma donde existen diferencias en la secuencia nucleotídica entre individuos de la misma especie, generando polimorfismos de un solo nucleótido (SNP) que se pueden identificar mediante la PCR-RFLP (3). Estos polimorfismos también pueden ser usados para conocer la estructura y diversidad poblacional (4). EI SNP A192G se encuentra en el exón 1 de la inhibina alfa (INHA), al ser una mutación sinónima no cambia la secuencia de aminoácidos de la proteína pero genera un sitio de restricción adicional para la endonucleasa MspI $(5,6)$. El SNPA-320T está localizado corriente arriba del gen del receptor de la hormona folículo estimulante (FSHR) y aunque 
The stimulating follicle hormone (FSH) has an essential role in oogenesis, allowing recruitment and follicular development, and acts exclusively through its receptor (FSHR) which is found on the surface of granulosa cells $(7,9)$. Inhibin regulates $\mathrm{FSH}$ levels affecting folliculogenesis (5). These polymorphisms have been associated with the response to superovulation and seminal quality, and it has been found that the INHA G allele exercises a positive effect on both traits, while the FSHR A allele improves seminal traits $(5,7,9)$. However, there are no studies on the effect of the principal parameters evaluated in the specialized dairy systems. The objective of this research was to analyze the structure and genetic diversity of a population of Holstein cattle based on A192G and A-320T polymorphisms of INHA and FSHR genes, and to determine the association of its interaction with the main productive and reproductive parameters estimated in the specialized dairy systems.

\section{MATERIALS AND METHODS}

Population study. The phenotypic information and the DNA samples were obtained from 356 Holstein cows (1240 lactation periods) from nine herds in seven municipalities of Antioquia (Table 1).

Table 1. Distribution of the animals studied by municipality and herd (N), and number of lactations analyzed by herd (N Lac).

\begin{tabular}{lcccc}
\hline \multicolumn{1}{c}{ Municipality } & N & Herd & N & N Lac \\
\hline Bello & 27 & $\mathrm{H}-1$ & 27 & 121 \\
Belmira & 38 & $\mathrm{H}-2$ & 38 & 145 \\
Entrerrios & & $\mathrm{H}-3$ & 45 & 184 \\
& 61 & $\mathrm{H}-4$ & 16 & 75 \\
San Pedro de los Milagros & 57 & $\mathrm{H}-6$ & 14 & 62 \\
& & $\mathrm{H}-7$ & 10 & 36 \\
La Unión & 57 & $\mathrm{H}-8$ & 57 & 105 \\
Medellín & 116 & $\mathrm{H}-9$ & 116 & 394 \\
\hline
\end{tabular}

Analysis of structure and population differentiation. The genomic DNA was obtained from blood samples using the modified Salting out method (10). To genotype the SNP A192G (GenBank number: rs41257116), a fragment of 249 bp of exon 1 was amplified using the primer F: 5'-GCCCTGTTTCTGGATGCC- ${ }^{\prime}$ and R: 5'-ATTCAACCCAACCTGCCTA-3' (5). The final reaction volume was $30 \mu \mathrm{l}$, and $3.8 \mu \mathrm{l}$ was used as buffer reaction 10X (200 nM $\left(\mathrm{NH}_{4}\right)_{2} \mathrm{SO}_{4}$ $750 \mathrm{mM}$ Tris- $\mathrm{HCl}$ pH 8.8 a $\left.25^{\circ} \mathrm{C}\right), 2.5 \mathrm{mM}$ of $\mathrm{MgCl}_{2}, 15 \mathrm{pmol}$ of primer, $0.4 \mathrm{mM}$ of dNTP no se encuentra en una región codificante puede modular la expresión del gen y además cambia el patrón de restricción obtenido con la enzima Taq1 $(7,8)$.

La hormona folículo estimulante (FSH) posee un rol esencial en la oogénesis, permitiendo el reclutamiento y el desarrollo folicular, esta hormona actúa exclusivamente a través de su receptor (FSHR) el cual se encuentra en la superficie de las células de la granulosa $(7,9)$. La inhibina se encarga de regular los niveles de FSH afectando la foliculogénesis (5). Estos polimorfismos han sido asociados con respuesta a la superovulación y características de calidad seminal, y se ha encontrado que el alelo $\mathrm{G}$ de INHA ejerce un efecto positivo en ambas características, mientras que el alelo A de FSHR mejora las características seminales $(5,7,9)$. Sin embargo no se encuentran estudios sobre su efecto en los principales parámetros evaluados en las lecherías especializadas. El objetivo de esta investigación fue analizar la estructura y diversidad genética de una población de bovinos Holstein a partir de los polimorfismos A192G y A-320T de los genes de INHA y FSHR, y determinar la asociación de su interacción con los principales parámetros productivos y reproductivos estimados en los sistemas de producción lechera especializados.

\section{MATERIALES Y MÉTODOS}

Población de estudio. La información fenotípica y las muestras de ADN se obtuvieron de 356 vacas Holstein (1240 lactancias) pertenecientes a nueve hatos en seis municipios de Antioquia (Tabla 1).

\section{Análisis de estructura y diferenciación} poblacional. El ADN genómico se obtuvo a partir de muestras de sangre con el método de Salting out modificado (10). Para la genotipificación del SNP A192G (GenBank number: rs41257116) se amplificó un fragmento de $249 \mathrm{pb}$ del exón 1 utilizando los primers F: 5'-GCCCTGTTTCTGGATGCC- $3^{\prime}$ y R: 5'-ATTCAACCCAACCTGCCTA-3' (5). El volumen final de reacción fueron $30 \mu \mathrm{l}$, se empelaron $3.8 \mu \mathrm{l}$ de buffer de reacción 10X (200 nM $\left(\mathrm{NH}_{4}\right)_{2} \mathrm{SO}_{4}, 750 \mathrm{mM}$ Tris- $\mathrm{HCl} \mathrm{pH} 8.8$ a $\left.25^{\circ} \mathrm{C}\right), 2.5$ $\mathrm{mM}$ de $\mathrm{MgCl}_{2}, 15 \mathrm{pmol}$ de primers, $0.4 \mathrm{mM}$ de dNTP (desoxirribonucleótidos trifosfato), 1.5 undidades de Taq-ADN polimerasa y $100 \mathrm{ng}$ de ADN genómico como muestra. Las condiciones de la PCR fueron 5 min a $95^{\circ} \mathrm{C}$, 34 ciclos de $94^{\circ} \mathrm{C}$ por $45 \mathrm{~s}, 62^{\circ} \mathrm{C}$ por $45 \mathrm{~s}$ para el alineamiento de los primers, $72^{\circ} \mathrm{C}$ por $45 \mathrm{~s}$ y $72^{\circ} \mathrm{C}$ por $10 \mathrm{~min}$ para la extensión final. La digestión se realizó con $15 \mu \mathrm{l}$ de producto de PCR, $7 \mathrm{U}$ de enzima MspI y 
(triphosphate deoxyribonucleotide), 1.5 units of Taq-DNA polymerase and 100 ng of genomic DNA as a template. The PCR conditions were $5 \mathrm{~min}$ at $95^{\circ} \mathrm{C}, 34$ cycles of $94^{\circ} \mathrm{C}$ for $45 \mathrm{~s}, 62^{\circ} \mathrm{C}$ for $45 \mathrm{~s}$ for annealing, $72^{\circ} \mathrm{C}$ for $45 \mathrm{~s}$ and $72^{\circ} \mathrm{C}$ for $10 \mathrm{~min}$ for the final extension. Digestion was done with $15 \mu \mathrm{l}$ of PCR product, $7 \mathrm{U}$ of MspI enzyme and $2.0 \mu \mathrm{l}$ of buffer in a final volume of $30 \mu \mathrm{l}$ for 8 hours at $37^{\circ} \mathrm{C}$. The amplified fragment contained two common restriction sites and one mutant (GGGAC) for the enzyme in positions 31,153 and 75 , respectively, generating three fragments (123, 95 and $31 \mathrm{bp}$ ) for allele $A$ and four fragments $(95,79,44$ and 31 bp) for allele $\mathrm{G}$. The digestion fragments were visualized using electrophoresis in agarose gel at $4 \%$.

To genotype the SNP A-320T (GenBank number: rs43676359) a fragment of 970 bp was amplified with the primers $\mathrm{F}$ : 5'-AGTTCGACCGCATCCCTG-3' and R: 5'-AATTCATTTGTGCCAGCATC-3' (7). The final reaction volume was $25 \mu \mathrm{l}$, and $3.1 \mu \mathrm{l}$ was used as buffer reaction $10 \mathrm{X}, 2.7 \mathrm{nM}$ of $\mathrm{MgCl}_{2}, 5$ pmol of primers, $0.24 \mathrm{mM}$ of dNTP, 1.5 units of Taq-DNA polymerase and 100 ng of genomic DNA as a template. The conditions of the PCR were 5 $\min$ at $95^{\circ} \mathrm{C}, 35 \mathrm{cycles}$ of $94^{\circ} \mathrm{C}$ for $30 \mathrm{~s}, 58^{\circ} \mathrm{C}$ for $30 \mathrm{~s}$ for annealing, $72^{\circ} \mathrm{C}$ for $30 \mathrm{~s}$ and $72^{\circ} \mathrm{C}$ for 8 min for the final extension. Digestion was done with $12 \mu \mathrm{l}$ of PCR product, $7 \mathrm{U}$ of TaqI and $1.6 \mu \mathrm{l}$ of buffer in a final volume $25 \mu$ for 16 hours at $65^{\circ} \mathrm{C}$. The amplified fragment contained four restriction sites ( $T$ 'CG_A) for the enzyme, resulting in five fragments (446, 293, 140, 86 and 5 bp) for A allele. Allele $T$ causes the loss of one of the restriction sites, generating four fragments (586, 293, 86 y 5 bp). The digestion fragments were visualized using electrophoresis in agarose gel at $3 \%$.

The allelic frequencies were determined using formulas $N_{A} / 2 N$ y $f_{a}=N_{a} / 2 N$ where $\mathrm{N}_{\mathrm{A}}$ and $\mathrm{N}_{\mathrm{a}}$ are the number of $\mathrm{A}$ and a alleles, in the population and $\mathrm{N}$ is the number of individuals. The genotype frequencies were determined with formulas $f_{A A}=N_{A A} / N, f_{A a}=N_{A a} / N$ y $f_{a a}=N_{a a} / N$ where $\mathrm{N}_{\mathrm{AA}}, \mathrm{N}_{\mathrm{Aa}}$ and $\mathrm{N}_{\mathrm{aa}}$ are the number of copies of genotypes $A A, A a$ and aa (11).

Genetic differentiation was determined comparing the observed heterozygosity ( $\mathrm{Ho}$ ) and the expected heterozygosity $(\mathrm{He})$, calculated with GenAlex software (12). The Hardy-Weinberg state of equilibrium (HWE) was determined based on allelic and genotypic frequencies observed and expected using GenAlex software (12).

The population structure was determined using Wright's F statistics: $F_{I S}=\left(H_{e}-H_{o}\right) / H_{e}$ , $F_{I T}=\left(H_{T}-H_{o}\right) / H_{T}, F_{S T}=\left(H_{T}-H_{e}\right) / H_{T}$ where $\mathrm{H}_{\mathrm{o}}$ and $\mathrm{H}_{\mathrm{e}}$ are the observed and expected
$2.0 \mu \mathrm{l}$ de buffer en un volumen final de $30 \mu \mathrm{l}$ por 8 horas a $37^{\circ} \mathrm{C}$. El fragmento amplificado contenía dos sitios de restricción comunes y uno mutante (GGGAC) para la enzima en las posiciones 31, 153 y 75, respectivamente, generando tres fragmentos (123, 95 y 31 pb) para el alelo A y cuatro fragmentos $(95,79,44$ y 31 pb) para el alelo G. Los fragmentos de digestión se visualizaron mediante electroforesis en gel de agarosa al $4 \%$.

Para la genotipificación del SNP A-320T (GenBank number: rs43676359) se amplificó un fragmento de 970 pb con los primers 5'-AGTTCGACCGCATCCCTG-3' y R: 5'-AATTCATTTGTGCCAGCATC-3' (7). El volumen final de reacción fueron $25 \mu \mathrm{l}$, se emplearon $3.1 \mu \mathrm{l}$ de buffer de reacción $10 \mathrm{X}, 2.7 \mathrm{nM}$ de $\mathrm{MgCl}_{2}, 5 \mathrm{pmol}$ de primers, $0.24 \mathrm{mM}$ de dNTP, 1.5 unidades de Taq-ADN polimerasa y 100 ng de ADN genómico como muestra. Las condiciones de la PCR fueron 5 min a $95^{\circ} \mathrm{C}, 35$ ciclos de $94^{\circ} \mathrm{C}$ por $30 \mathrm{~s}, 58^{\circ} \mathrm{C}$ por $30 \mathrm{~s}$ para el alineamiento de los primers, $72^{\circ} \mathrm{C}$ por $30 \mathrm{~s}$ y $72^{\circ} \mathrm{C}$ por $8 \mathrm{~min}$ para la extensión final. La digestión se llevó a cabo con $12 \mu \mathrm{l}$ de producto de PCR, $7 \mathrm{U}$ de TaqI y $1.6 \mu$ de buffer en un volumen final de $25 \mu$ por 16 horas a $65^{\circ} \mathrm{C}$. El fragmento amplificado contenía cuatro sitios de restricción ( $T$ 'CG_A) para la enzima, resultando en cinco fragmentos $(446,293,140,86$ y 5 pb) para el alelo A. El alelo T causa la pérdida de uno de los sitios de restricción, generando cuatro fragmentos (586,293,86 y 5pb). Los fragmentos de digestión se visualizaron mediante electroforesis en gel de agarosa al $3 \%$.

Las frecuencias alélicas se determinaron mediante las fórmulas $N_{A} / 2 N$ y $f_{a}=N_{a} / 2 N$ donde $\mathrm{N}_{\mathrm{A}}$ y $\mathrm{N}_{\mathrm{a}}$ son el número de alelos $\mathrm{A}$ y a en la población y $\mathrm{N}$ es el número de individuos. Las frecuencias genotípicas se determinaron con las fórmulas $f_{A A}=N_{A A} / N, f_{A a}=N_{A a} / N$ y $f_{a a}=N_{a a} / N$ donde $\mathrm{N}_{\mathrm{AA}}, \mathrm{N}_{\mathrm{Aa}}$ y $\mathrm{N}_{\text {aa }}$ son el número de copias de los genotipos AA, Aa y aa (11).

La diferenciación genética se determinó mediante la comparación de la heterocigosidad observada $(\mathrm{Ho})$ y la heterocigosidad esperada $(\mathrm{He})$, calculadas con el software GenAlex (12). El estado de equilibrio de Hardy-Weinberg (HWE) se determinó con base en las frecuencias alélicas y genotípicas observadas y esperadas utilizando el software GenAlex (12).

La estructura poblacional se determinó mediante los estadísticos F de Wright; $F_{I S}=\left(H_{e}-H_{o}\right) / H_{e}$, $F_{I T}=\left(H_{T}-H_{o}\right) / H_{T}, F_{S T}=\left(H_{T}-H_{e}\right) / H_{T}$ donde $\mathrm{H}_{\text {o }}$ y $\mathrm{H}_{\mathrm{e}}$ son la heterocigosidad observada y esperada entre subpoblaciones y $\mathrm{H}_{\mathrm{T}}$ es la heterocigosidad total esperada. Estos se obtuvieron utilizando el software GenAlex mediante el método de Análisis de Varianza Molecular (AMOVA). El flujo genético 
heterozygosity among subpopulations and $\mathrm{H}_{\mathrm{T}}$ is the total expected heterozygosity. These were obtained using GenAlex software with the Molecular Variance Analysis (AMOVA) method. The genetic flow expressed as the number of migrants $(\mathrm{Nm})$ was determined with the formula $N m=\left[\left(1 / F_{S T}\right)-1\right] / 4(13)$.

With the $F_{S T}$ values paired among subpopulations, the UPGMA tree was built using MEGA 6 software (14).

The linkage disequilibrium was evaluated using a linkage disequilibrium coefficient which was calculated with GenAlex software using the formula $D_{A B}=f_{A B}-f_{A} f_{B}$ (11) where $\mathrm{f}_{A B}$ is the frequency of the combination of $A B$ alleles and $f_{A}$ and $f_{B}$ is the allelic frequency of $A$ and $B$ respectively; and using the correlation coefficient through sets of loci with the formula $r^{2}=D^{2} /\left(f_{A} f_{a} f_{B} f_{b}\right)(11)$.

\section{Association of interaction of INHA and FSHR genotypes with productive and reproductive efficiency. The analyzed parameters were} milk yield adjusted to 305 days (PAJUS), protein percentage (PP) and fat (PG) as quality indicators and somatic cell count (SCC) as a health indicator. The analyzed reproductive parameters were calving interval (IEP) and services per conception (SPC). The SCC was transformed to its logarithmic form with the formula SCS $=3+\log _{2}(\mathrm{SCC} / 100)$ (15). To achieve a better balance in data, the births occurring between 1998 and 2003 were grouped in the year 2003; those in 2004 and 2005 were grouped in 2005; and those that occurred between 2011 and 2014 were grouped in 2014. The sixth to the eleventh lactation were grouped in the sixth lactation. The associations of genotypes with the productive and reproductive efficiency of Holstein cows were determined with a Mixed Linear Model. Tukey test was used to determine significant differences between the measurements obtained for fixed effects included in the model. This statistical analysis was done with SAS software (16). The statistical model used was:

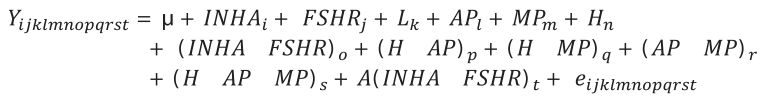

Where $Y_{i j k l m n o p a r s t}$ is the dependent variable, which could be PAJUS, PP, PG, SCS, IEP or SPC, $\mu$ is the mean for the trait in the population; INHA is the fixed effect of the INHA genotype [1-3]; $F_{S H R}$ is the fixed effect of the FSHR genotype $[1-3] ; L_{k}$ is the fixed effect of the lactating number [1-6]; $A P_{1}$ is the fixed effect of the birth year[1-8]; $\mathrm{MP}_{\mathrm{m}}$ is the fixed effect of the birth month [1-12]; $H_{n}$ is the fixed effect of the herd [1-9]; expresado como el número de migrantes $(\mathrm{Nm})$ se determinó con la formula $N m=\left[\left(1 / F_{S T}\right)-1\right] / 4(13)$.

Con los valores de $F_{S T}$ pareados entre las subpoblaciones se construyó el árbol de UPGMA utilizando el software MEGA 6 (14).

El desequilibrio de ligamiento se evaluó a partir del coeficiente desequilibrio de ligamiento el cual se calculó con el software GenAlex mediante la fórmula $D_{A B}=f_{A B}-f_{A} f_{B}$ (11) donde $\mathrm{f}_{\mathrm{AB}}$ es la frecuencia de la combinación de alelos $A B$ y $f_{A}$ y $f_{B}$ es la frecuencia alélica de $A$ y $B$ respectivamente; y mediante el coeficiente de correlación mediante pares de loci, con la fórmula $r^{2}=D^{2} /\left(f_{A} f_{a} f_{B} f_{b}\right)(11)$.

Asociación de la interacción de genotipos de INHA y FSHR con eficiencia productiva y reproductiva. Los parámetros analizados fueron producción de leche ajustada a 305 días (PAJUS), porcentaje de proteína (PP) y grasa (PG) como indicadores de calidad y conteo de células somáticas (SCC) como indicador de sanidad. Los parámetros reproductivos analizados fueron intervalo entre partos (IEP) y servicios por concepción (SPC). El SCC se transformó a su forma logarítmica con la fórmula $S C S=3+\log _{2}(S C C / 100)(15)$. Para lograr un mejor balance en los datos, los nacimientos ocurridos entre 1998 y 2003 se agruparon en el año 2003; los ocurridos entre 2004 y 2005 se agruparon en 2005; y los ocurridos entre 2011 y 2014 se agruparon en 2014. De la sexta a la undécima lactancia se agruparon en la sexta lactancia. Las asociaciones de los genotipos con la eficiencia productiva y reproductiva de vacas Holstein se determinaron con un Modelo Linear Mixto. La prueba de Tukey se usó para determinar diferencias significativas entre las medias obtenidas para los efectos fijos incluidos en el modelo. Este análisis estadístico se realizó con el software SAS (16). El modelo estadístico usado fue:

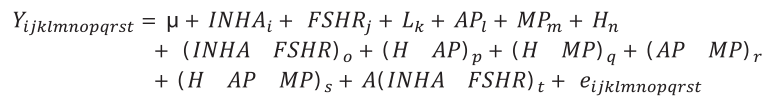

Donde $Y_{i j k l m n o p a r s t}$ es la variable dependiente, que pudo ser PAJUS, PP, PG, SCS, IEP o SPC, $\mu$ es la media para la característica en la población; INHA $_{i}$ es el efecto fijo del genotipo de INHA [1-3]; $\mathrm{FSHR}_{\mathrm{j}}$ es el efecto fijo del genotipo de FSHR [1-3]; $L_{k}$ es el efecto fijo del número de lactancia [1-6]; $\mathrm{AP}_{\text {, }}$ es el efecto fijo del año de parto [1-8]; $\mathrm{MP}_{\mathrm{m}}$ es el efecto fijo del mes de parto [1-12]; $H_{n}$ es el efecto fijo del hato [1-9]; (INHA*FSHR)。 es el efecto fijo de la interacción entre ambos genotipos; $\left(\mathrm{H}^{*} \mathrm{AP}\right)_{\mathrm{p}}$ es el efecto fijo de la interacción entre hato y año de parto; $\left(\mathrm{H}^{*} \mathrm{MP}\right)_{\mathrm{q}}$ es el efecto fijo de la interacción entre 
(INHA*FSHR)。 is the fixed effect of the interaction between both genotypes; $\left(H^{*} A P\right)$ is the fixed effect of the interaction between herd and birth year; $\left(H^{*} M P\right)_{a}$ is the fixed effect of the interaction between herd and birth month; (AP*MP) is the fixed effect of the interaction between birth month and year; $\left(H^{*} A P^{*} M P\right)_{s}$ is the fixed effect of the interaction between herd, birth year and month; $A(I N H A * F S H R)$, is the random effect of the interaction of the nested genotypes with the animal and $\mathrm{e}_{\mathrm{ijk} \text { kmnoparst }}$ is the random error. In addition to these effects, the real production of milk (PREAL) and the length of lactation (DL) were included as covariates in the PP and FT models. For SCS, IEP and SPC, the PAJUS was also included as a covariate, and additionally for SPC the IEP was included, that corresponded to the analyzed lactation as a covariate.

\section{RESULTS}

Allelic frequencies and genotypes. The PCR product corresponding to a fragment of the exon 1 of INHA gene presented two common restriction sites and a mutating one for the MspI enzyme generating three or four fragments for the $A$ and G allele, respectively (Figure 1).

The PCR product corresponded to a fragment of the $5^{\prime}$ UTR region of the FSHR gene that contained four restriction sites for the TaqI enzyme when the $A$ allele was present, and three restriction sites when the $T$ allele was present, generating five or four fragments, respectively (Figure 2 ).

For INHA the allelic frequencies were 0.534 and 0.466 for $A$ and $G$ respectively. The genotype frequencies were $0.269,0.529$ and 0.201 for $A A$, AG and GG respectively. For FSHR, the frequency was 0.660 and 0.339 for the $T$ and $A$ allele respectively. The genotype frequencies found for $A A, A T$ and $T T$ were $0.096,0.485$ and 0.417 respectively (Table 2 ).

Hardy-Weinberg equilibrium. The total population did not present significant differences among observed $(\mathrm{Ho}=0.504 \pm 0.028)$ and expected $(\mathrm{He}=0.466 \pm 0.013)$ heterozygosity for both genes (Table 3 ). The majority of the subpopulations were found in HWE for both genes, except the subpopulations in Entrerrios and La Unión. The subpopulation in Entrerrios showed a significant reduction in the number of heterozygotes expected for the INHA polymorphism, while the subpopulation of La Unión had an excess number of expected heterozygotes for FSHR polymorphism.

Genetic structure. The $F_{S T}$ statistic for the total population was $0.059(p=0.001)$ indicating a low differentiation between the subpopulations. The hato y mes de parto; (AP*MP), es el efecto fijo de la interacción entre mes y año de parto; $\left(H^{*} A P^{*} M P\right)_{s}$ es el efecto fijo de la interacción entre hato, año y mes de parto; A(INHA*FSHR) t es el efecto aleatorio de la interacción de los genotipos anidado con el animal y $e_{i j k \text { mnoparst }}$ es el error aleatorio. Además de estos efectos, la producción real de leche (PREAL) y la duración de la lactancia (DL) se incluyeron como covariables en los modelos para PP y FT. Para SCS, IEP y SPC también se incluyó la PAJUS como covariable, adicionalmente para SPC se incluyó el IEP, correspondiente a la lactancia analizada como covariable.

\section{RESULTADOS}

Frecuencias alélicas y genotípicas. El producto de PCR correspondiente a un fragmento del exón 1 del gen de INHA presentó dos sitios de restricción comunes y uno mutante para le enzima MspI generando tres o cuatro fragmentos para los alelos A y $\mathrm{G}$ respectivamente (Figura 1 ).

El producto de PCR correspondiente a un fragmento de la región 5'UTR del gen de FSHR contenía cuatro sitios de restricción para la enzima TaqI cuando estaba el alelo A, y tres sitios de restricción cuando estaba el alelo T, generando cinco o cuatro fragmentos respectivamente (Figura 2).

Para INHA las frecuencias alélicas fueron 0.534 y 0.466 para A y $G$ respectivamente. Las frecuencias genotípicas fueron $0.269,0.529$ y 0.201 para AA, AG y GG respectivamente. Para FSHR la frecuencia fue de 0.660 y 0.339 para el alelo $T$ y $A$ respectivamente. Las frecuencias genotípicas encontradas para AA, AT y $T$ fueron $0.096,0.485$ y 0.417 respectivamente (Tabla 2 ).

Equilibrio de Hardy-Weinberg. La población total no presentó diferencias significativas entre la heterocigosidad observada $(\mathrm{Ho}=0.504 \pm 0.028)$ y la esperada $(\mathrm{He}=0.466 \pm 0.013)$ para ambos genes (Tabla 3). La mayoría de las subpoblaciones se encontraron en HWE para ambos genes, excepto las subpoblaciones de Entrerrios y La Unión. La subpoblación de Entrerrios presentó una reducción significativa en el número de heterocigotos esperados para el polimorfismo de INHA mientras que la subpoblación de La Unión presentó un exceso en el número de heterocigotos esperados para el polimorfismo de FSHR.

Estructura genética. El estadístico $F_{S T}$ para la población total fue $0.059(p=0.001)$ indicando una baja diferenciación entre las subpoblaciones. El valor obtenido de $\mathrm{F}_{\mathrm{IS}}$ para la población total fue 

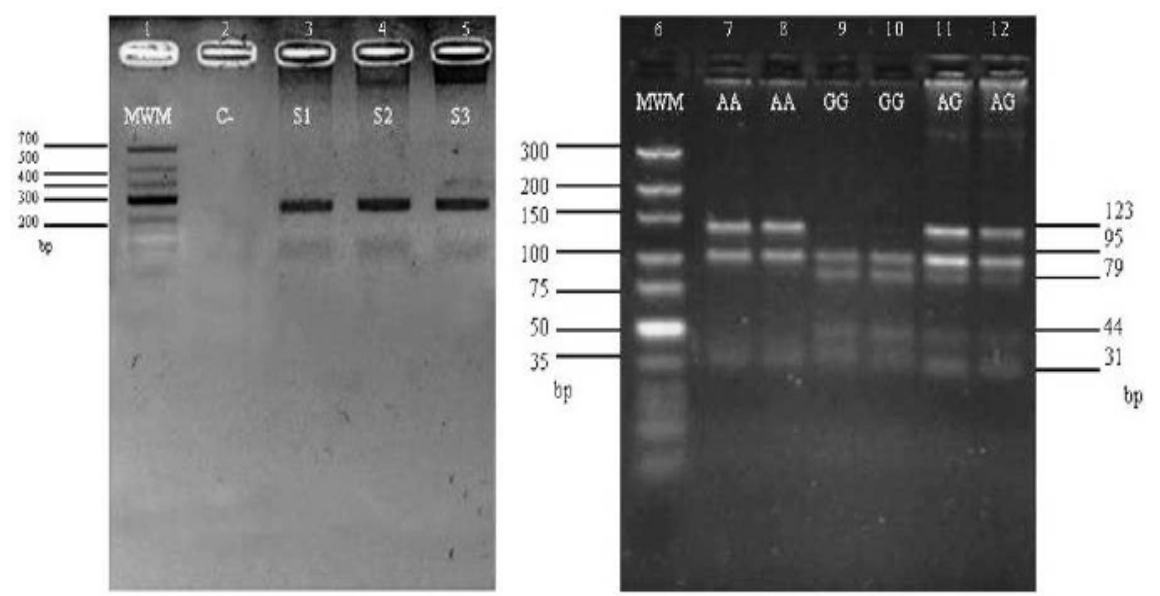

Figure 1. Amplified fragment (249 bp) of the inhibin alpha gene (lines 3 to 5 ) and the restriction pattern after digesting the MspI enzyme for each genotype (AA lines 7 and 8, GG lines 9 and 10, AG lines 11 and 12); lines 1 and 6 correspond to the molecular weight marker and line 2 corresponds to the negative control (PCR without DNA template).
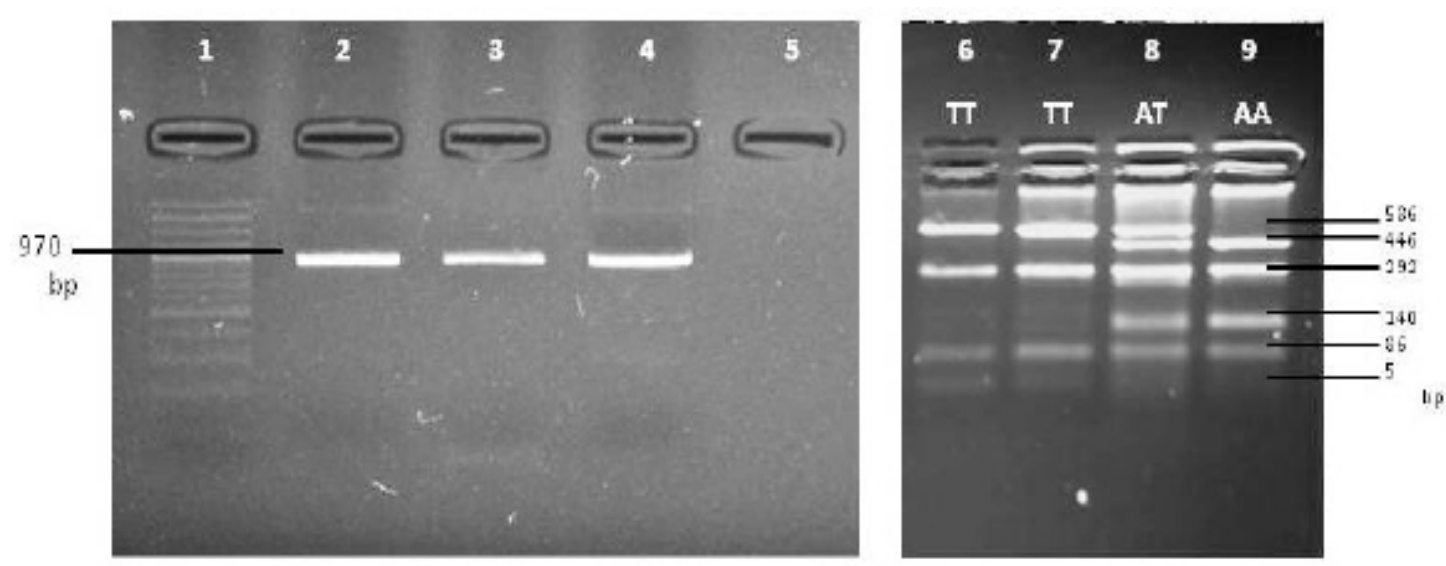

Figure 2. Amplified fragment ( $970 \mathrm{bp}$ ) of follicle stimulating hormone receptor gene (lines 2 to 4 ) and restriction pattern after digestion of TaqI for each genotype (TT lines 6 and 7, AT line 8 and AA line 9); line 1 corresponds to the molecular weight marker and line 5 to the negative control (PCR without DNA sample).

Table 2. Allelic and genotypic frequencies for inhibin alpha and follicle stimulating hormone receptor genes in a Holstein population belonging to diverse municipalities in the department of Antioquia.

\begin{tabular}{|c|c|c|c|c|c|c|c|c|c|c|}
\hline \multirow{3}{*}{ Town } & \multicolumn{5}{|c|}{ INHA } & \multicolumn{5}{|c|}{ FSHR } \\
\hline & \multirow{2}{*}{$\frac{\text { Allelic }}{\text { A }}$} & \multirow{2}{*}{$\frac{\text { frequencies }}{\text { G }}$} & \multicolumn{3}{|c|}{ Observed genotypic frequencies } & \multicolumn{2}{|c|}{ Allelic frequencies } & \multicolumn{3}{|c|}{ Observed genotypic frequencies } \\
\hline & & & AA & AG & GG & A & $\mathbf{T}$ & AA & AT & TT \\
\hline Bello & 0.500 & 0.500 & 0.200 & 0.500 & 0.300 & 0.220 & 0.780 & 0.038 & 0.461 & 0.500 \\
\hline Belmira & 0.575 & 0.425 & 0.270 & 0.540 & 0.189 & 0.338 & 0.662 & 0.100 & 0.300 & 0.600 \\
\hline Entrerrios & 0.469 & 0.531 & 0.288 & 0.389 & 0.322 & 0.386 & 0.614 & 0.157 & 0.605 & 0.236 \\
\hline San Pedro & 0.593 & 0.407 & 0.277 & 0.555 & 0.166 & 0.333 & 0.667 & 0.036 & 0.509 & 0.454 \\
\hline La Unión & 0.500 & 0.500 & 0.370 & 0.444 & 0.185 & 0.382 & 0.618 & 0.137 & 0.392 & 0.470 \\
\hline Medellín & 0.540 & 0.460 & 0.216 & 0.630 & 0.153 & 0.329 & 0.671 & 0.102 & 0.500 & 0.398 \\
\hline Total & 0.534 & 0.466 & 0.269 & 0.529 & 0.201 & 0.339 & 0.661 & 0.096 & 0.485 & 0.417 \\
\hline
\end{tabular}

$F_{\text {IS }}$ value obtained for the total population was $0.285(p=0.010)$, indicating a slight tendency towards endogamy within the subpopulations, in the total population also seen a slight tendency $0.285(p=0.010)$ indicando un tendencia baja a la endogamia dentro de las subpoblaciones, en la población total también se observa una leve tendencia a la endogamia, representado 
Table 3. Observed heterozygosity ( $\mathrm{Ho}$ ), expected heterozygosity $(\mathrm{He})$ and $\mathrm{P}$ value of the Chisquared test for some Holstein populations in the department of Antioquia.

\begin{tabular}{|c|c|c|c|c|}
\hline Town & & Ho & $\mathrm{He}$ & Valor $\mathbf{P}$ \\
\hline \multirow{3}{*}{ Bello } & FSHR & 0.440 & 0.343 & 0.158 \\
\hline & INHA & 0.474 & 0.500 & 0.819 \\
\hline & Media & 0.457 & 0.422 & \\
\hline \multirow{3}{*}{ Belmira } & FSHR & 0.568 & 0.447 & 0.102 \\
\hline & INHA & 0.650 & 0.489 & 0.140 \\
\hline & Media & 0.609 & 0.468 & \\
\hline \multirow{3}{*}{ Entrerrios } & FSHR & 0.455 & 0.474 & 0.784 \\
\hline & INHA & 0.354 & 0.498 & 0.045 \\
\hline & Media & 0.404 & 0.486 & \\
\hline \multirow{3}{*}{ La Unión } & FSHR & 0.608 & 0.472 & 0.040 \\
\hline & INHA & 0.623 & 0.500 & 0.074 \\
\hline & Media & 0.615 & 0.486 & \\
\hline \multirow{3}{*}{ Medellín } & FSHR & 0.457 & 0.441 & 0.763 \\
\hline & INHA & 0.584 & 0.497 & 0.062 \\
\hline & Media & 0.521 & 0.469 & \\
\hline \multirow{3}{*}{ San Pedro } & FSHR & 0.392 & 0.444 & 0.401 \\
\hline & INHA & 0.444 & 0.483 & 0.559 \\
\hline & Media & 0.418 & 0.464 & \\
\hline Total & & 0.504 & 0.466 & \\
\hline
\end{tabular}

towards endogamy, represented in the $\mathrm{F}_{\mathrm{IT}}$ value obtained, which was $0.328(p=0.10)$.

The mean flow value of genes represented as the number of migrants ( $\mathrm{Nm}$ ) was 4 individuals per generation; this value represents the movement of individuals or gametes among the subpopulations, promoting a genetic interchange among subpopulations.

Genetic differentiation. The paired $\mathrm{F}_{\mathrm{ST}}$ were between 0.006 and 0.174 (Table 4), presenting significant differences indicating degrees of differentiation between the subpopulations from low to medium. The studied subpopulations can be grouped in two branches; the subpopulations of Bello and Belmira are those that are farthest from the genetic tree, while the subpopulations of Entrerrios, La Unión, Medellín and San Pedro de los Milagros show less genetic differentiation (Figure 3).

Table 4. Statistic for $F_{S T}$ paired among Holstein populations in the department of Antioquia.

\begin{tabular}{|c|c|c|c|c|c|}
\hline & Bello & Belmira Entrerrio & sLa Unión & Medellín & $\begin{array}{c}\text { San } \\
\text { Pedro }\end{array}$ \\
\hline Bello & 0.000 & & & & \\
\hline Belmira & 0.013 & 0.000 & & & \\
\hline Entrerrios & $0.034 * *$ & $0.067 * * * 0.000$ & & & \\
\hline La Unión & $0.039 * *$ & $0.094 * * * 0.020 *$ & 0.000 & & \\
\hline Medellín & $0.109 * * *$ & $0.174 * * * 0.025 * *$ & $0.047 * * *$ & 0.000 & \\
\hline San Pedro & $0.040 * *$ & $0.102 * * * 0.036 * *$ & 0.006 & $0.049 * * *$ & 0.000 \\
\hline
\end{tabular}

por el valor obtenido de $F_{I T}$ el cual fue de 0.328 $(p=0.10)$.

El valor medio de flujo de genes representado como el número de migrantes $(\mathrm{Nm})$ fue de 4 individuos por generación, este valor representa el movimiento de individuos o gametos entre las subpoblaciones promoviendo el intercambio genético entre subpoblaciones.

Diferenciación genética. LoS $\mathrm{F}_{\mathrm{ST}}$ pareados estuvieron entre 0.006 y 0.174 (Tabla 4) presentando diferencias significativas, indicando grados de diferenciación entre las subpoblaciones desde baja hasta media. Las subpoblaciones estudiadas se pueden agrupar en dos grandes ramas; las subpoblaciones de Bello y Belmira son las más alejadas en el árbol genético, mientras que entre las subpoblaciones de Entrerrios, La Unión, Medellín y San Pedro de los Milagros se presenta menor diferenciación genética (Figura 3).

Desequilibrio de ligamiento. Para la población Holstein analizada la combinación de genotipos más frecuente fue el doble heterocigoto AGAT con una frecuencia de $24.45 \%$ mientras que la combinación de genotipos menos frecuente fue el doble homocigoto AAAG con una frecuencia de 1.31\% (Tabla 5).

Los valores de $D$ y $r^{2}$ por población no fueron significativamente diferentes de cero (datos no mostrados). La población total presentó un $D=0.016$ y un $r^{2}=0.066$ pero estos valores no fueron significativos $(p>0.05)$ indicando que presencia de los alelos de un locus es independiente de la presencia de los alelos del otro locus.

\section{Asociación de genotipos de INHA-FSHR con características de importancia económica.}

Análisis descriptivo. La media para PAJUS para la población Holstein de Antioquia fue 5.588 \pm 1.492 L/lac, con PP y PG de $3.06 \pm 0.26$ y $3.89 \pm 0.46$ respectivamente. Para SCS se encontró una media de 4.19 \pm 1.01 . La media para el IEP fue $414 \pm 85$ con $1.67 \pm 1.17$ SPC (Tabla 6 ).

\section{Asociación de genotipos de INHA-FSHR con características productivas.}

Producción de leche. Las variables $L, H$, FSHR las interacciones $\mathrm{H}^{*} \mathrm{AP}, \mathrm{H}^{*} \mathrm{MP}$ y $\mathrm{H}^{*} \mathrm{AP} * \mathrm{MP}$ tuvieron un efecto altamente significativo $(p<0.01)$. Las demás variables no mostraron efecto significativo en la característica $(p>0.05)$.

Porcentaje de proteína. La PREAL presentó efecto significativo en esta características $(p<0.05)$, las demás variables no presentaron efecto significativo ( $p>0.05)$. 

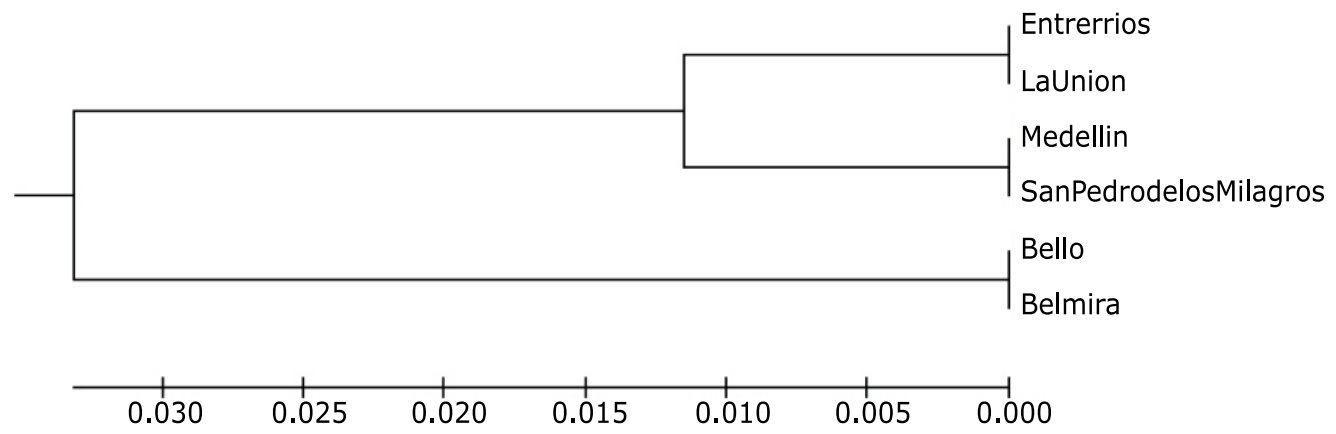

Figure 3. Dendrogram based on the $F_{S T}$ paired for six subpopulations of Holstein cows in the department of Antioquia.

Linkage disequilibrium. For the analyzed Holstein population, the most frequent combination of genotypes was the double heterozygote AGAT with a frequency of $24.45 \%$, while the less frequent combination of genotypes was the double homozygote AAAG with a frequency of $1.31 \%$ (Table 5).
Porcentaje de grasa. Ninguna de las variables incluidas en el modelo presentó un efecto significativo para la característica $(p>0.05)$.

Asociación de genotipos de INHA-FSHR con características sanitarias.

Puntaje de células somáticas. Ninguna de las variables incluidas en el modelo presentó un efecto significativo para la característica $(p>0.05)$.

Table 5. Tukey measurements for the production of milk adjusted (PAJUS), protein percentage (PP), fat percentage $(P G)$, somatic cells score (SCS), calving interval (IEP) and services per conception (SPC) according to the combination of genotypes of inhibin alpha and follicle stimulating hormone receptor for Antioquia Holstein cows.

\begin{tabular}{|c|c|c|c|c|c|c|c|c|c|}
\hline \multirow[b]{2}{*}{ Evaluated trait } & \multicolumn{9}{|c|}{ GENOTYPE COMBINATIONS INHA/FSHR } \\
\hline & AAAA & AAAT & AATT & AGAA & AGAT & AGTT & GGAA & GGAT & GGTT \\
\hline $\mathrm{N}$ & 9 & 30 & 24 & 14 & 56 & 49 & 3 & 24 & 20 \\
\hline$\%$ & 3.93 & 13.10 & 10.48 & 6.11 & 24.45 & 21.40 & 1.31 & 10.48 & 8.73 \\
\hline PAJUS (L/lac) & $6282+\S$ & 5721 & $5278 *+$ & 5543 & 5746 & 5659 & $6657 * \neq$ & 5576 & $5271 \neq \S$ \\
\hline PP (\%) & 3.01 & 3.11 & 3.10 & 3.09 & 3.01 & 3.11 & 3.07 & 3.04 & 3.10 \\
\hline PG (\%) & 3.80 & 3.84 & 3.98 & 3.91 & 3.85 & 4.02 & 3.65 & 3.94 & 3.92 \\
\hline SCS & $4.96 *$ & 4.18 & 4.34 & $3.97 *$ & 4.17 & 4.40 & 3.78 & 4.21 & 4.50 \\
\hline IEP (días) & 419 & 404 & $395^{*}$ & $374+$ & 419 & 417 & 463 & $455 *+$ & 389 \\
\hline SPC & 2.00 & 2.07 & 1.71 & 1.47 & $2.38 *$ & 2.10 & 2.20 & 2.09 & $1.30 *$ \\
\hline
\end{tabular}

Number of individuals $(\mathrm{N})$ and frequency (\%) of each genotype combination

$*+\neq \S$ Significant differences according to the Tukey test
Tum

The $D$ and $r^{2}$ values per population were not significantly different from zero (data not shown). The total population showed $D=0.016$ and $r^{2}=0.066$ but these values were not significant $(p>0.05)$, indicating that the presence of alleles in one locus is independent of the presence of alleles in another locus.

\section{Association of INHA-FSHR genotypes with economically important traits.}

Descriptive analysis. The PAJUS mean for the Antioquia Holstein population was $5.588 \pm 1.492 \mathrm{~L} /$ lac, with PP and PG at $3.06 \pm 0.26$ and $3.89 \pm 0.46$ respectively. For SCS a mean of $4.19 \pm 1.01$ was found. The mean for IEP was $414 \pm 85$ with $1.67 \pm 1.17$ SPC (Table 6).
Tabla 6. Mean, standard deviation (DE), variation coefficient (CV) and number of observations (N) for adjusted milk production (PAJUS), protein percentage (PP), fat percentage (PG), somatic cells score (SCS), calving interval (IEP) and services per conception (SPC) for Antioquia Holstein cows.

\begin{tabular}{lcccc}
\hline Evaluated trait & Mean & DE & CV & N \\
\hline PAJUS (L/lac) & 5588 & 1492 & 26.70 & 811 \\
PP (\%) & 3.06 & 0.26 & 8.56 & 421 \\
PG (\%) & 3.89 & 0.46 & 12.04 & 421 \\
SCS & 4.19 & 1.01 & 24.13 & 413 \\
IEP (días) & 414 & 85 & 20.53 & 876 \\
SPC & 1.67 & 1.17 & 69.85 & 1091 \\
\hline
\end{tabular}




\section{Association of INHA-FSHR genotypes with productive traits.}

Milk production. The $L, H, F S H R$ variables with $\mathrm{H}^{*} \mathrm{AP}, \mathrm{H}^{*} \mathrm{MP}$ y $\mathrm{H}^{*} \mathrm{AP} * \mathrm{MP}$ interactions had a highly significant effect $(p<0.01)$. The other variables did not have a significant effect on the trait $(p>0.05)$.

Protein percentage. The PREAL had a significant effect on this trait $(p<0.05)$, the other variables did not have a significant effect ( $p>0.05)$.

Fat percentage. None of the variables included in the model presented a significant effect on the trait $(p>0.05)$.

\section{Association of INHA-FSHR genotypes with health traits.}

Somatic cells scores. None of the variables included in the model presented a significant effect on this trait $(p>0.05)$.

\section{Association of INHA-FSHR genotypes with reproductive traits.}

Calving interval. The AP*MP interaction had a significant effect on the trait $(p<0.05)$. The other variables did not have a significant effect $(p>0.05)$.

Services per conception. None of the variables included in the model presented a significant effect on this trait $(p>0.05)$.

The mean of each trait for each combination of genotypes is shown in table 6 .

\section{DISCUSSION}

The A192G and A-320T polymorphisms have been studied in other populations, such as the Holstein China population $(5,7,9)$. For cows of the Holstein China population, have reported that the A and G alleles of SNP A192G have a frequency of 0.55 y 0.45 respectively, similar to the frequencies found for the Antioquia Holstein population. In the Holstein cows of both populations, the most frequent genotype was AG, however for the population of Holstein China bulls the most common genotype was the $A A(5,7)$. For the Holstein China bulls a frequency of 0.691 was reported for the A allele and 0.309 for the T allele $(5,7)$.

Respecting the A-320T polymorphism, for the Holstein China population a frequency was found for the $A$ and $T$ alleles of 0.301 and 0.699 in females, while in males it was 0.321 and 0.679 , respectively. For this population, the most common genotype is $\Pi$, in males and females, while in Antioquia is more common the heterozygous $(7,9)$.
Asociación de genotipos de INHA-FSHR con características reproductivas.

Intervalo entre partos. La interacción $A P * M P$ tuvo un efecto significativo sobre la característica $(p<0.05)$. Las demás variables no tuvieron efecto significativo $(p>0.05)$.

Servicios por concepción. Ninguna de las variables incluidas en el modelo presentó un efecto significativo para la característica $(p>0.05)$.

Las medias de cada característica para cada combinación de genotipos se muestran en la tabla 6.

\section{DISCUSIÓN}

Los polimorfismos A192G y A-320T han sido estudiados en otras poblaciones, como la población Holstein China $(5,7,9)$. Para las vacas de la población Holstein china se ha reportado que los alelos A y G del SNP A192G tienen una frecuencia de 0.55 y 0.45 respectivamente, similar a las frecuencias encontradas para la población Holstein de Antioquia. En las vacas Holstein de ambas poblaciones el genotipo más frecuente fue el AG, sin embargo para la población de toros Holstein de China el genotipo más común fue el AA $(5,7)$. Para los toros Holstein chinos, se reportó una frecuencia de 0.691 para el alelo A y de 0.309 para el alelo $T(5,7)$.

Respecto al polimorfismo A-320T, para la población Holstein China se encontró una frecuencia para los alelos A y T de 0.301 y 0.699 en hembras, mientras que en machos fue de 0.321 y 0.679 , respectivamente. Para esa población el genotipo más común es el $\Pi$, en machos y hembras, mientras que en Antioquia es más común el heterocigoto $(7,9)$.

A pesar que en la población total se observa un mayor número de individuos heterocigotos que el esperado, esta diferencia no es significativa por lo cual la población total se encuentra en HWE. Solamente dos poblaciones, La Unión y Entrerrios, no se encontraron en HWE, la primera por un aumento significativo de los animales heterocigotos indicando una tendencia a la exogamia, y la segunda por una reducción significativa de los mismos mostrando una tendencia a la endogamia. Dentro de las poblaciones existen varias fuerzas que pueden generar desviaciones del HWE, como lo son el apareamiento selectivo, la endogamia, la estructura poblacional y la selección, pero son la endogamia y la estructura poblacional las principales razones que pueden generar 
In spite of the fact that in the total population a greater number of heterozygote individuals was found than was expected, this difference is not significant, since the total population is found in HWE. Only two populations, La Unión and Entrerrios, were not in HWE, the first due to a significant increase of heterozygote animals, indicating a tendency to exogamy, and the second due to a significant reduction of the same, showing a tendency towards endogamy. Within the populations there are several factors that can generate HWE deviations, such as selective pairing, endogamy, population structure and selection, but endogamy and population structure are the main factors that generate HWE deviations due to small differences in the allelic frequencies between subpopulations (11). However, for populations in La Unión and Entrerrios, it is expected that HWE deviations are due to selection processes on traits that can be associated with these polymorphisms, causing an indirect selection and therefore affecting the allelic and genotypic frequencies.

The endogamy coefficient of a subdivided population $\left(F_{\text {IT }}\right)$ can be divided using Wright's $F$ statistics between the component due to non-random pairing within subpopulations $\left(F_{\text {IS }}\right)$ and the subdivision between populations (FST) (13). For the analyzed population, the $F_{\text {IT }}$ value obtained $(0.328)$ reflects a low tendency to endogamy; in the same way, the $F_{\text {IS }}$ value obtained $(0.285)$ indicates a slight tendency to homozygosity due to non-random pairing between individuals in each subpopulation. The $F_{S T}$ value for the total population (0.059) indicates that a moderate differentiation between the populations exists, which represents a reduction in the heterozygosity due to population subdivision.

The Wright $\mathrm{F}_{\mathrm{ST}}$ statistic measures the subdivision of the population and determines if differences exist in the allelic frequencies among the subpopulations. The populations that showed a greater degree of differentiation were Medellín and Belmira, while the populations in La Unión and San Pedro had less differentiation. This can be explained by the technical level implemented in each of these municipalities, with higher levels in the municipalities of Medellín, San Pedro and La Unión in comparison to Belmira, and therefore among the populations with a higher technical level; in terms of genetic improvement strategies that are implemented, mainly artificial insemination, the $\mathrm{F}_{\mathrm{ST}}$ values are less than 0.05, indicating little or no differentiation. Due to this differentiation, the subpopulations in Antioquia do not act like one population. desviaciones en el HWE debido a pequeñas diferencias en las frecuencias alélicas entre las subpoblaciones (11). Sin embargo para las poblaciones de La Unión y Entrerrios se espera que estas desviaciones del HWE se deban a procesos de selección sobre las características que puedan estar asociadas a estos polimorfismos, causando una selección indirecta de los mismos, y por tanto afectando sus frecuencias alélicas y genotípicas.

Los estadísticos $\mathrm{F}$ de Wright permiten dividir el coeficiente de endogamia de una población subdividida $\left(F_{I T}\right)$ entre el componente debido al apareamiento no aleatorio dentro de las subpoblaciones $\left(F_{\text {IS }}\right)$ y la subdivisión entre poblaciones $\left(F_{S T}\right)(13)$. Para la población analizada el valor de $\mathrm{F}_{\mathrm{IT}}$ obtenido $(0.328)$ refleja una baja tendencia la endogamia; de igual manera el valor de obtenido de $F_{\text {IS }}$ (0.285) indica una leve tendencia a la homocigosidad debido al apareamiento no aleatorio entre los individuos de cada subpoblación. El valor de $F_{S T}$ para la población total $(0.059)$ indica que existe una moderada diferenciación genética entre las poblaciones, esto representa una reducción en la heterocigosidad debida a la subdivisión poblacional.

El estadístico $\mathrm{F}_{\mathrm{ST}}$ de Wright mide la subdivisión de la población y determina si existen diferencias en las frecuencias alélicas entre las subpoblaciones. Las poblaciones que mostraron un mayor grado de diferenciación fueron Medellín y Belmira, mientras que las poblaciones de La Unión y San Pedro presentaron la menor diferenciación. Esto puede explicarse en el nivel de tecnificación implementado en cada uno de estos municipios, siendo más alto en los municipios de Medellín, San Pedro y La Unión en comparación a Belmira, es por esto que entre las poblaciones con mayor nivel de tecnificación; en términos de las estrategias de mejoramiento genético implementadas, principalmente la inseminación artificial, los valores de $\mathrm{F}_{\mathrm{ST}}$ son menores de 0.05 , indicando poca o nula diferenciación. Debido a esta diferenciación las subpoblaciones de Antioquia no se comportan como una sola población.

La estructura y diferenciación de la población Holstein del departamento de Antioquia también ha sido evaluada a partir de polimorfismos de otros genes como lactoferrina (LTF) y la hormona de crecimiento bovina (bGH). Con base en el gen LTF se encontró que la población de vacas Holstein se encontraba en HWE, y a nivel de subpoblación solo el municipio de San Pedro de los Milagros presentó desviaciones del HWE posiblemente debido a una intensa selección, ya que este es uno de los municipios 
The structure and differentiation of the Holstein population in the department of Antioquia has also been evaluated using polymorphisms of different genes such as lactoferrine (LTF) and the bovine growth hormone (bGH). Based on the LTF gene, the Holstein cow population was found to have HWE, and at the subpopulation level only the municipality of San Pedro de los Milagros presented HWE deviations, possibly due to an intense selection, since this is one of the most important municipalities in the dairy sector in the department (17). This investigation reports for the population a $F_{I S}=-0.0717$, indicating a tendency to exogamy. Upon evaluating this population based on the bGh gene, it was also found to be in HWE. Although the total population reported a $\mathrm{F}_{\mathrm{ST}}=0.0068$, a certain degree of differentiation was found among the subpopulations, the municipality of Marinilla being the one that presented the greatest genetic differentiation (4).

$\mathrm{Nm}$ represents the absolute number of migrant organisms that enter each subpopulation in each generation. This flux of individuals causes a rapid decrease in the fixation index. Thus, migration exercises an important force against genetic divergence between subpopulations (18). For the population analyzed, a total of four migrants per generation was found. Although it is affirmed that if $N m>1$ the subpopulations evolve as just one population, it is more correct to affirm that there is no population subdivision if $N m>10$ (11). This could explain the genetic differentiation found among subpopulations in the department of Antioquia; although there is genetic flux between them, it has not been sufficient to homogenize the allelic frequencies, although it could be thought that the populations are in a process of homogenization. In other studies $(4,19)$, the number of migrants that has been reported is much greater than what was found in this investigation. Based on a SNP, the growth hormone gene (bGH) was reported for the Holstein population in Antioquia at $\mathrm{Nm}=36$ (4), while based on the SNP of the lactoferrine gene (LTF), Nm=25 has been reported for the same population (19). This high value could be due to implementing artificial insemination that eliminates geographic barriers and increases the genetic flux between populations $(4,19)$.

The polymorphisms analyzed are found in linkage equilibrium, that is, the observed frequency to combine genotypes does not significantly differ from the expected frequency. In this way, it can be asserted that the presence of each allele for each gene analyzed is independent of the presence of any other. Since in bovines the INHA and FSHR genes are found in different más importantes para el sector lechero en el departamento (17). Esta investigación reporta para la población un $\mathrm{F}_{\mathrm{IS}}=-0.0717$ indicando una tendencia a la exogamia. Al evaluar esta misma población con base en el gen bGH también se encontró en HWE. Aunque para la población total se reportó un $\mathrm{F}_{\mathrm{ST}}=0.0068$, se encontró cierto grado de diferenciación entre las subpoblaciones, siendo el municipio de Marinilla el que presentaba la mayor diferenciación genética (4).

El $N m$ representa el número absoluto de organismos migrantes que entran a cada subpoblación en cada generación. Este flujo de individuos causa una rápida disminución en el índice de fijación. Así, la migración ejerce una fuerza importante contra la divergencia genética entre subpoblaciones (18). Para la población analizada se encontró un total de cuatro migrantes por generación. Aunque se afirma que si el $N m>1$ las subpoblaciones evolucionan como una sola población, es más acertado afirmar que no existe subdivisión poblacional si el $N m>10$ (11). Esto podría explicar la diferenciación genética encontrada entre las subpoblaciones del departamento de Antioquia; aunque existe flujo genético entre ellas este no ha sido suficiente para homogenizar las frecuencias alélicas, sin embargo se puede pensar que las poblaciones se encuentran en un proceso homogenización. En otros estudios $(4,19)$ se ha reportado un número de migrantes mucho mayor al encontrado en esta investigación. Con base en un SNP del gen de hormona de crecimiento (bGH) se reportó para la población Holstein de Antioquia un $N m=36$ (4), mientras que con base en un SNP del gen de lactoferrina (LTF) se ha reportado un $N m=25$ para la misma población (19). Este alto valor puede deberse a la implementación de la inseminación artificial que permite eliminar las barreras geográficas y aumentar el flujo genético entre las poblaciones $(4,19)$.

Los polimorfismos analizados se encuentran en equilibrio de ligamiento, es decir que la frecuencia observada para combinación de genotipos no difiere de manera significativa de su frecuencia esperada. De esta manera se puede afirmar que la presencia de cada alelo para cada uno de los genes analizados es independiente de la presencia de cualquier otro de ellos. Como en los bovinos los genes de INHA y FSHR se encuentran en cromosomas diferentes, 2 y 11 respectivamente, estos poseen una tasa de recombinación máxima, es decir 0.5 , confirmando su segregación independiente de acuerdo con la segunda ley de Mendel (11).

La media para producción de leche fue mayor que el valor reportado en otra investigación (4.482 L/ 
chromosomes, 2 and 11 respectively, these have a maximum recombinant rate, that is, 0.5 , confirming their independent segregation according to the second law of Mendel (19).

The mean milk yield was greater than values reported in other investigations (4.482 L/lac ) for the Holstein Antioquia population (20). However, in other studies a greater value ( 7.155 L/lac) for milk production has been found for this population (21). The PP found in this investigation was less than that found by other investigators $(3.16 \%)$, and on the other hand, the mean found for PG was greater than the value reported in literature $(3.37 \%)$ (20). Regarding reproductive parameters, the SPC and IEP averages were very similar to the average reported in a previous investigation, where a mean of 1.67 and 453 days, respectively, was found (22).

The interaction of the studied polymorphisms did not present a significant effect on the majority of the traits that are of Zootechnical interest, however this interaction makes the A-320T polymorphism have a significant effect on the PAJUS, which had not been discovered when analyzing it independently (data not shown). For A-320T polymorphism, the AA individuals evidenced a greater productive level $(5.902 \mathrm{~L} /$ lac), with 193 and 381 L/lac more than the AT and $\Pi$ individuals respectively. The AA individuals also showed a lesser IEP value in comparison with the other genotypes (403 days) (data not shown). Since AA individuals present greater reproductive efficiency, reflected in a lower IEP, it would be expected that these individuals present shorter lactation periods, which when they adjusting to 305 days show improvement and a greater production level is obtained. When analyzing the combination of alleles for these genes, the GGAA and AAAA individuals are those that present the greatest productive levels, confirming that the A allele for FSHR is associated with greater production. Regarding the milk solid content, the AGTT individuals present the greatest percentages of fat and protein. In parallel studies that were done, it was found that the $G$ allele in INHA is associated with greater PG, while the FSHR T allele is related to greater PG and PP, since the FSHR T allele is also related to a greater volume of milk, causing a minor dilution effect on milk solids.

A lower IEP value was found in AAAT individuals, while a greater value was found in GGAA, a difference that could be due to INHA alleles, since the $A$ allele is associated with a lesser IEP while GG individuals have greater values for this trait. The lesser SPC number was for GGTT individuals and the greater one for AGAT, but it cannot be lac ) para la población Holstein de Antioquia (20). Sin embargo en otros estudios han encontraron un valor mayor (7.155 L/lac) de producción de leche para esta población (21). El PP encontrado en esta investigación fue menor que el encontrado por otros investigadores (3.16\%), por otro lado, la media encontrada para PG fue mayor que el valor reportado en la literatura (3.37\%) (20). En cuanto a los parámetros reproductivos, los promedios de SPC e IEP fueron muy similares al promedio reportado en una investigación previa, donde se encontró una media de 1.67 y 453 días, respectivamente (22).

La interacción de los polimorfismos estudiados no presentó un efecto significativo en la mayoría de las características de interés zootécnico, sin embargo, esta interacción causa que el polimorfismo A-320T presente un efecto significativo para la PAJUS, el cual no había sido evidenciado al analizarlo de forma independiente (datos no mostrados). Para el polimorfismo A-320T los individuos AA presentaron el mayor nivel productivo (5.902 L/ lac), con 193 y 381 L/lac más que los individuos AT y $\Pi T$ respectivamente. Los individuos AA también presentaron el menor valor de IEP en comparación con los otros genotipos (403 días) (datos no mostrados). Como los individuos AA presentan una mayor eficiencia reproductiva, reflejada en un menor IEP, se podría esperar que estos individuos presenten lactancias más cortas, que al momento de ajustarlas a 305 días se vean favorecidas y por lo tanto se obtenga un mayor nivel de producción. Al analizar la combinación de alelos para ambos genes, son los individuos GGAA y AAAA los que presentan los mayores niveles productivos, confirmando que el alelo A de FSHR está asociado con mayor producción. Respecto al contenido de sólidos en leche los individuos AGTT presentan los mayores porcentajes grasa y proteína. En estudios realizados de forma paralela se encontró que el alelo G de INHA está asociado con mayor PG, mientras que el alelo T de FSHR está relacionado con mayor PG y PP, debido a que el alelo T de FSHR también se relaciona con menor volumen de leche causando un menor efecto de dilución de los sólidos en la leche.

El menor IEP lo tuvieron los individuos AAAT mientras que el mayor fue para los GGAA, esta diferencia puede deberse a los alelos de INHA ya que el alelo A se asocia con un menor IEP mientras que los individuos GG presentan mayores valores para esta característica. El menor número de SPC fue para los individuos GGTT y el mayor para los AGAT, pero no se puede afirmar que alguno de los alelos analizados presente una tendencia a aumentar o disminuir el valor de esta característica. 
stated that one of the analyzed alleles presents a tendency to increase or decrease the value of this trait.

Based on this information, we can conclude that selection based on the phenotype in the population of Holstein Antioquia cows has not been sufficiently strong to generate HardyWeinberg equilibrium deviations or diminished in any notable way the frequency of any alleles for the studied polymorphisms, and therefore a great diversity exists among the populations. This genetic diversity greatly important, since individuals can respond adequately to diverse environmental challenges, and additionally it is the starting point to begin genetic improvement programs that seek to increase productive and reproductive efficiency in animal production systems. More studies are needed to determine if these polymorphisms can be useful in molecular marker selection programs and it is recommended that better control over environmental factors be exercised in order to make it easier to detect the effect these polymorphisms could have on the evaluated zootechnical traits.
Con base en esta información se puede concluir que la selección basada en el fenotipo que se realiza en la población de vacas Holstein de Antioquia no ha sido lo suficientemente fuerte para generar desviaciones del equilibrio de Hardy-Weinberg ni ha logrado disminuir de manera notable la frecuencia de ninguno de los alelos de los polimorfismos estudiados, por lo cual existe gran diversidad entre las poblaciones. Esta diversidad genética es de gran importancia ya que permite a los individuos responder de forma más adecuada a diversos retos ambientales, y además es el punto de partida para realizar los programas de mejoramiento genético que buscan aumentar la eficiencia productiva y reproductiva en los sistemas de producción animal. Son necesarios más estudios para determinar si estos polimorfismos pueden ser útiles en los programas de selección asistida por marcadores moleculares y para estos se recomienda realizar un mejor control de los factores ambientales con el fin de evidenciar más fácilmente el efecto que estos polimorfismos puedan tener sobre las características zootécnicas evaluadas.

\section{REFERENCES}

1. Boichard D, Maignel L, Verrier E. The value of using probabilities of gene origin to measure genetic variability in a population. Genet Sel Evol 1997; 29:5-23.

2. Muasya T, Peters K, Kahi A. Breeding structure and genetic variability of the Hosltein Friesian dairy cattle population in Kenia. Anim Genet Resour 2013; 52:127-132.

3. Deb R, Chakraborty S, Singh U. Molecular Markers and Their Application in Livestock Genomic Research. J Vet Sci Technol 2012; 3(2):7579.

4. Rincón JC, López A. Echeverri JJ. Estructura y diversidad genética en vacas Holstein de Antioquia usando un polimorfismo del gen bGH. Rev. MVZ Córdoba 2013; 18(1):3346-3354.

5. Tang KQ, LiSJ, Yang WC, Yu JN, Han L, LiX etal. An MspI polymorphism in the inhibin alpha gene and its associations with superovulation traits in Chinese Holstein cows. Mol Biol Rep 2011; 38(1):17-21.

6. National Center for Biotechnology information. ReferenceSNP (refSNP) Cluster Reportrs41257116. 2013. Disponible en: http://www.ncbi.nlm.nih. gov/projects/SNP/snp_ref.cgi?rs=41257116
7. $\quad$ Sang L, Du QZ, Yang WC, Tang KQ, Yu JN, Hua G et al. Polymorphisms in follicle stimulation hormone receptor, inhibin alpha, inhibin beta $\mathrm{A}$, and prolactin genes, and their association with sperm quality in Chinese Holstein bulls. Anim Reprod Sci 2011; 126(3-4):151-156.

8. National Center for Biotechnology information. ReferenceSNP (refSNP) Cluster Reportrs43676359. 2013. Disponible en: http://www.ncbi.nlm.nih.gov/ projects/SNP/snp_ref.cgi?rs=43676359.

9. Yang WC, Li SJ, Tang KQ, Hua GH, Zhang CY, Yu $\mathrm{JN}$ et al. Polymorphisms in the $5^{\prime}$ upstream region of the FSH receptor gene, and their association with superovulation traits in Chinese Holstein cows. Anim Reprod Sci 2010; 119(3-4):172-177.

10. Miller $S$, Dykes D, Polesky H. A simple salting out procedure for extracting DNA from human nucleated cells. Nucleic Acids Res 1988; 16(3):1215.

11. Nielsen R, Slatkin M. An Introduction to Population Genetics. Theory and Applications. Sunderland, Massachussets. USA: Sinauer Associates, Inc. Publishiers, 2013, p. 287. 
12. Peakall R, Smouse PE. GenAlEx 6.5: genetic analysis in Excel. Population genetic software for teaching and research--an update. Bioinformatics 2012; 28(19):2537-2539.

13. Piñero D, Barahona A, Eguiarte L, Rocha A, Salas R. La variabilidad genética de las especies: aspectos conceptuales y sus aplicaciones y perspectivas en México. En: Díaz P, Morales E, Zizumbo-Villarreal D, editores. Capital Natural de México. México; 2008; p. $415-435$.

14. Hall B. Building phylogenetic trees from molecular data with MEGA. Mol Biol Evol 2013; 30(5):12291235

15. Rodríguez-Zas SL, Gianola D, Shook GE. Evaluation of models for somatic cell score lactation patterns in Holsteins. Livest Prod Sci 2000; 67(1-2):19-30.

16. SAS Institute Inc., Cary, NC, USA, 2009.

17. Rodríguez N, López A, Echeverri JJ. Diversidad Genética de un Polimorfismo del Gen de Lactofernina Bovino (LTF) en una Población de Vacas Holstein de Colombia y su Asociación con Componentes de la Leche (Resultados Preliminares). Actas Iberoam Conserv Anim 2011; 1(1):151-153.
18. Hartl DL, ClarkAG. Principles of population genetics. 4th ed. Sunderland, Massachusetts: Sinauer Associates, Inc. Publishiers, 2007.

19. Rodríguez N, López A, Echeverri JJ. Estructura genética poblacional del gen lactoferrina bovino en vacas Holstein del departamento de Antioquia. Rev MVZ Córdoba 2013; 18(1):3355-3361.

20. Echeverri JJ, Salazar V, Parra JE. Análisis comparativo de los grupos genéticos Holstein, Jersey y algunos de sus cruces en un hato lechero del Norte de Antioquia en Colombia. Zootec Trop 2011; 29(1):49-59.

21. Corrales J, Cerón-Muñoz M, Cañas J, Herrera C, Calvo S. Parámetros genéticos de características de tipo y producción en ganado Holstein del departamento de Antioquia. Rev MVZ Córdoba 2011; 17(1):2870-2877.

22. Madrid S, Echeverri JJ. Association Between Conformation Traits and Reproductive Traits in Holstein Cows in the Department of Antioquia - Colombia. Rev Fac Nac Agron Medellín 2014; 67(2):7311-7319. 